\title{
International Law Obligations of States in Undelimited Maritime Frontier Areas
}

\author{
Robin Churchill
}

The geographical position of the overwhelming majority of coastal States means that the maritime zones that they may claim off their coasts (territorial sea, contiguous zone, exclusive economic zone (EEZ) and continental shelf) overlap with the maritime zones of one or more neighbouring States. It has been estimated that there are about 430 areas worldwide where one or more of the maritime zones of neighbouring States overlap. ${ }^{1}$ Around 250 such areas of overlap have already been delimited, totally or partially, ${ }^{2}$ by a definitive boundary, either as a result of a treaty between the States concerned ${ }^{3}$ or, less frequently, by an international court or tribunal. 4 That leaves roughly 18 o overlapping areas where no boundary exists. Such undelimited areas may be characterized as maritime frontier areas in the sense in which the term 'frontier' is used in this book.

The aim of this chapter is to try to establish what international law obligations States have in undelimited maritime frontier areas, in particular obligations designed to avoid the lawlessness and sub-optimal utilization of resources often associated with such areas. In the present context such lawlessness may result from each of the States whose maritime zones overlap seeking to exercise jurisdiction in the overlapping area not only over ships having its own

1 JRV Prescott and CH Schofield, The Maritime Political Boundaries of the World (2nd ed, Martinus Nijhoff, 2005) 435 .

2 An example of a partial delimitation would be where the overlapping territorial seas of two adjacent States had been delimited, but not their EEzs.

3 For a list of maritime boundary treaties, see British Institute of International and Comparative Law (BIICL), Report on the Obligations of States under Articles 74(3) and 83(3) of UNCLOS in respect of Undelimited Maritime Areas (BIICL, 2016) 125-170 (hereafter BIICL Report).

4 Twenty-four areas had been delimited by judicial decision as at July 2019. Delimitation of three further areas was pending before an international court or tribunal. For a slightly dated list of cases where a court or tribunal has determined a maritime boundary, see YTanaka, The International Law of the Sea (2nd ed, Cambridge University Press, 2015) 208. 
nationality but also over foreign ships, including ships having the nationality of the other State. Such action is likely to provoke disputes and may even lead to the use of force. As regards the sub-optimal utilization of resources, oil companies are usually, although not invariably, reluctant to engage in exploitation of hydrocarbon resources without the certainty of knowing which State has undisputed sovereign rights to the resources of the continental shelf in the area concerned. ${ }^{5}$ By contrast, fishing in undelimited maritime frontier areas may result in over-exploitation of the resource because neighbouring States fail to cooperate over its management as they dispute which of them has management rights, while vessels from third States may be tempted to fish without the permission of the coastal States as they know that those States are in dispute as to which has the competence to license and exercise jurisdiction over them.

As will become apparent, international law obligations in maritime frontier areas vary, depending on which maritime zone(s) the frontier area comprises. This chapter therefore considers the various maritime frontier zones separately, beginning with the position where the EEzs and the continental shelves within 200 nautical miles (M) of the baselines (hereafter inner continental shelves) of neighbouring States overlap. The chapter then moves on to address the situation where continental shelves beyond $200 \mathrm{M}$ overlap, before dealing with overlapping territorial seas. It might seem more logical to consider the territorial sea first, as the maritime zone closest to the coast, but the international law obligations applying there present an interesting contrast with the obligations applying in areas further seawards, and this contrast is more readily appreciated if the latter areas are discussed first. There is no separate discussion of the position where contiguous zones overlap since those zones are subsumed within the EEZ and current international law contains no provisions regarding their delimitation. In the sections on the various maritime zones, the discussion will be in terms of the obligations contained in the United Nations Convention on the Law of the Sea (LOSC), ${ }^{6}$ to which the overwhelming majority of the 150 or so coastal States are parties. ${ }^{7}$ However,

5 See NA Ioannides, 'The Legal Framework governing Hydrocarbon Activities in Undelimited Maritime Areas' (2019) 68 International and Comparative Law Quarterly 345-368, 359 and literature quoted there. He gives the example of an announcement by the French oil company, Total, in 2018 that it would not operate within the area where the maritime boundary between Israel and Lebanon is disputed.

6 United Nations Convention on the Law of the Sea (LOSC), adopted 10 December 1982, in force 16 November 1994, 1833 UNTS 3.

7 For a list of parties, see https://www.un.org/depts/los/reference_files/status2o19.pdf; accessed 6 August 2019. 
there are 14 coastal States that are not parties to the Convention and to which its obligations therefore do not apply. ${ }^{8}$ The penultimate section of the chapter therefore considers what obligations (if any) apply to such States. The chapter ends with some brief conclusions.

\section{Obligations in Areas of Overlapping EEZ s and Inner Continental Shelves ${ }^{9}$}

The position regarding overlapping EEZs and inner continental shelves will be considered together, both because the LOSC contains identical obligations in each case (in Articles 74 and 83) and because for States that claim an $\mathrm{EEZ}$ (which is most States ${ }^{10}$ ) the continental shelf coincides with the seabed of the EEZ. In practice, the majority of States seek to delimit a single maritime boundary rather than separate and different boundaries for overlapping EEZs and inner continental shelves in order to avoid the complications that may arise where one State has sovereign rights to exploit the resources of the superjacent water column, while another State has sovereign rights over the resources of the seabed. Conflicts may occur, for example, if the second State wishes to engage in exploitation of oil and gas in an area that is an important fishing ground for nationals of the first State. International courts and tribunals have held that Articles 74 and 83 apply equally to the delimitation of single maritime boundaries as to the delimitation of separate boundaries for each of the EEZ and continental shelf. ${ }^{11}$

$8 \quad$ Ibid.

9 This section draws to a considerable extent on the BIICL Report, above (n 3$)$. The author of this chapter was a member of the research team that produced the report and was responsible for the first draft of that part of the Report on which this section draws.

10 Nearly 130 out of a total of some 15 o coastal States claim an EEz (the author's calculation, based, with some updating, on the undoAlos Table of Claim to Maritime Jurisdiction, showing the position as at 2011, http://www.un.org/Depts/los/ LEGISLATIONANDTREATIES/PDFFILES/table_summary_of_claims.pdf; accessed 6 August 2019.

11 See, for example, Case concerning the Land and Maritime Boundary between Cameroon and Nigeria (Cameroon v Nigeria, Equatorial Guinea intervening), Judgment, (2002) ICJ Reports, p 303, paras 285-286; Arbitration between Barbados and Trinidad and Tobago, Award, (2006) XXVII RIAA 147, paras 234-235; Case concerning Maritime Delimitation in the Black Sea (Romania v Ukraine), Judgment, (2009) ICJ Reports, p 61, paras 17, 31; Delimitation of the Maritime Boundary in the Bay of Bengal (Bangladesh/Myanmar), Judgment, 14 March 2012, ITLOS Reports 2012, p 4, paras 182-184; Territorial and Maritime Dispute (Nicaragua v Colombia), Judgment, (2012) ICJ Reports, p 624, para 139; Maritime Dispute (Peru v Chile), Judgment, (2014) ICJ Reports, p 3, para 179; Bay of Bengal Maritime 
Articles 74 and 83 are identical apart from the fact that in Article 83 the words 'exclusive economic zone' that are used in Article 74 are replaced by 'continental shelf'. The articles read as follows:

1. The delimitation of the [EEz/continental shelf] between States with opposite or adjacent coasts shall be effected by agreement on the basis of international law, as referred to in Article 38 of the Statute of the International Court of Justice, in order to achieve an equitable solution.

2. If no agreement can be reached within a reasonable period of time, the States concerned shall resort to the procedures provided for in Part XV.

3. Pending agreement as provided for in paragraph 1 , the States concerned, in a spirit of understanding and cooperation, shall make every effort to enter into provisional arrangements of a practical nature and, during this transitional period, not to jeopardize or hamper the reaching of the final agreement. Such arrangements shall be without prejudice to the final delimitation.

4. Where there is an agreement in force between the States concerned, questions relating to the delimitation of the [EEz/continental shelf] shall be determined in accordance with the provisions of that agreement. These provisions thus set out four obligations on States where their EEZs and continental shelves overlap, namely:

1. To effect a delimitation of their overlapping zones by agreement (Articles $74(1)$ and $83(1))$.

2. To resort to the dispute settlement procedures of Part XV of the LOSC where no agreement can be reached within a reasonable period of time (Articles 74(2) and 83(2)).

3. Pending an agreement, to make every effort to enter into provisional arrangements of a practical nature (Articles 74(3) and 83(3)).

4. Not to jeopardize or hamper the reaching of a boundary agreement (Articles 74(3) and 83(3)).

The content and scope of each of these obligations will be examined in turn.

\subsection{The Obligation to Effect a Delimitation of Overlapping Zones by Agreement}

This obligation requires the States concerned to enter into negotiations to establish a maritime boundary. ${ }^{12}$ The scope of an obligation to negotiate was

Boundary Arbitration (Bangladesh v India), Award, 7 July 2014, PCA Case No 2010-16, para 312.

12 Cameroon/Nigeria case, above (n 11), para 244; Maritime Delimitation in the Indian Ocean (Somalia v Kenya), Preliminary Objections, Judgment, (2017) ICJ Reports, p 3, para 9o; 
spelt out in general terms by the International Court of Justice (ICJ) in the North Sea cases. According to the Court:

[T] he parties are under an obligation to enter into negotiations with a view to arriving at an agreement, and not merely to go through a forma1 process of negotiation as a sort of prior condition for the automatic application of a certain method of delimitation in the absence of agreement; they are under an obligation so to conduct themselves that the negotiations are meaningful, which will not be the case when either of them insists upon its own position without contemplating any modification of it ... [I]n its Advisory Opinion in the case of Railway Traffic between Lithuania and Poland, [the Permanent Court of International Justice] said that the obligation was "not only to enter into negotiations but also to pursue them as far as possible with a view to concluding agreements", even if an obligation to negotiate did not imply an obligation to reach agreement. ${ }^{13}$

In the Cameroon/Nigeria case, the ICJ, referring explicitly to Articles 74 and 83, emphasized that while negotiations must be conducted in good faith, it was not a requirement that they be successful. ${ }^{14}$

Thus, negotiations under Articles 74 and 83 must be conducted in good faith and be meaningful in the sense described in the North Sea cases. The aim of the negotiations, according to the articles, is to 'achieve an equitable solution' 'on the basis of international law'. Logic suggests that any maritime boundary on which the parties are genuinely agreed, without one party having been coerced

Dispute concerning Delimitation of the Maritime Boundary between Ghana and Côte d'Ivoire in the Atlantic Ocean (Ghana/Côte d'Ivoire), Judgment, 23 September 2017, ITLOS Reports 2017, p 4, para 604.

13 North Sea Continental Shelf cases (Federal Republic of Germany v Denmark; Federal Republic of Germany $v$ The Netherlands), Judgment, (1969) ICJ Reports, p 3, paras 85, 87 (omitting footnotes in the original). See also Application of the International Convention on the Elimination of All Forms of Racial Discrimination (Georgia $v$ Russian Federation), Preliminary Objections, Judgment, (2011) ICJ Reports, p 70, paras 157-161, which contains a similar but slightly more detailed explanation of what is involved in the obligation to negotiate. In particular, the obligation to negotiate in good faith is emphasized.

14 Cameroon/Nigeria case, above (n 11), para 244. So, too, Somalia v Kenya, above (n 12), para 9o. In the Ghana/Côte d'Ivoire case the Special Chamber of the ITLos noted that the obligation to negotiate was an obligation of conduct, not of result: see Ghana/Côte d'Ivoire case (n 12), at para 604 . 
by the other in some way, ${ }^{15}$ must be considered to be an 'equitable solution'. If the parties are happy with the boundary, it is not open to a third party to argue that the boundary is inequitable. As regards the phrase, 'on the basis of international law', discussion here will be confined to seeking to identify the meaning of 'on the basis of'. To consider what is meant by 'international law' in this context would take us into the substantive law of maritime boundary delimitation, which lies beyond the scope of this chapter. ${ }^{16}$ The phrase 'on the basis of' does not appear to have been the object of judicial comment, but its ordinary meaning would suggest that States need not strictly adhere to international law when negotiating a maritime boundary. In any case, there is so much flexibility in the relevant international law that the requirement of Articles 74 and 83 that an agreement must be 'effected ... on the basis of international law' is in practice unlikely to be a constraining factor on States in negotiating a boundary.

A further element of the obligation to negotiate concerns paragraph 4 of Articles 74 and 83 . This provides that ' $[\mathrm{w}]$ here there is an agreement in force between the States concerned, questions relating to the delimitation of the [EEZ/continental shelf] shall be determined in accordance with the provisions of that agreement'. At first sight this provision might appear redundant. If there is an agreement in force, why would States still be negotiating a maritime boundary agreement? However, the provision does have some potential purpose or application. For example, there may already be an agreement in force between the States concerned setting out principles to be applied in a future maritime delimitation. That was the position in the Black Sea case, for example. ${ }^{17}$ Or there may be an agreement that has already delimited part of the boundary. ${ }^{18}$ Conceivably, there could be a tacit agreement establishing part of the boundary, as the ICJ found to be the situation in the Peru/ Chile case. ${ }^{19} \mathrm{~A}$ further possibility might be where the States concerned were successors to a prior agreement between States to whose treaties they had succeeded.

15 Coercion would invalidate a boundary agreement: see Arts $5^{1}$ and $5^{2}$ of the Vienna Convention on the Law of Treaties, adopted 23 May 1969, in force 27 January 1980, 1155 UNTS 331. Any fraud or corruption would also invalidate an agreement: see Arts 49 and 5 o.

16 For discussion of what it embraces, see the BIICL Report, above (n 3), 10-11.

17 Black Sea case, above (n 11), paras 27, 33, 41.

18 Cf. ibid para 69.

19 Peru/Chile case, above (n 11), paras 90-91. 

Part XV of the LOSC Where No Agreement Can Be Reached within a Reasonable Period of Time

Articles 74(2) and 83(2) oblige States to resort to the dispute settlement procedures of Part XV '[i]f no agreement [on a maritime boundary] can be reached within a reasonable period of time'. That raises the question of whether the States concerned are obliged to wait until 'a reasonable period of time' has elapsed before referring an unresolved maritime boundary to the dispute settlement procedures of Part XV or whether one of them may refer a dispute unilaterally to such procedures before the elapse of 'a reasonable period of time'. In the Barbados/Trinidad and Tobago case, in which Barbados had unilaterally instituted arbitration proceedings against Trinidad and Tobago, the arbitral tribunal implied that the former was the case since it discussed whether 'a reasonable period time of time' had actually elapsed. As regards that question, the tribunal found that as the parties had held nine rounds of negotiations over a period of nearly three and a half years without approaching agreement, 'a reasonable period of time' had elapsed. ${ }^{20}$ The Timor-Leste/Australia Conciliation Commission took a rather different approach. The Commission was faced with applying, not Articles 74(2) and 83(2) of the LOSC, but a very similar provision in Article 298(1)(a)(i), which stipulates that a State may unilaterally initiate conciliation proceedings relating to a maritime boundary dispute only where 'no agreement within a reasonable period of time is reached in negotiations between the parties'. The Commission observed that this provision 'does not expressly require that prior negotiations between the parties to the dispute actually take place. Such a requirement would effectively grant a party the right to veto any recourse to compulsory conciliation by refusing to negotiate, contrary to the intentions of Article 298.21 The Commission found that negotiations had in fact taken place. Thus, it did not have to consider whether Article 298 might at least require a party initiating conciliation proceedings to have called on the other party beforehand to engage in negotiations.

Although the obligation to resort to the dispute settlement procedures of the LOSC is couched in mandatory terms in Articles 74(2) and 83(2), it is obvious that if neither of the parties wishes to refer the matter to a court or tribunal after what might be considered a 'reasonable period of time' for negotiations, they cannot in practice be compelled to do so, but may continue to negotiate

20 Barbados/Trinidad and Tobago case, above (n 11), paras 194-200.

21 Conciliation between the Democratic Republic of Timor-Leste and the Commonwealth of Australia, Decision on Australia's Objection to Competence, 19 September 2016, PCA Case No 2016-10, para 78 . 
in the hope that they will eventually reach agreement on a boundary. It would also seem to be the case that the parties may, by agreement, refer a maritime boundary dispute to the dispute settlement procedures of Part XV, regardless of how much time had elapsed since the dispute arose.

As regards 'the procedures provided for in Part XV' to which Articles 74(2) and $83(2)$ refer, they include both diplomatic and judicial means of dispute settlement. In the case of diplomatic means, the reference in Articles 74(2) and $8_{3}(2)$ must be to third party means since by definition at least one of the States concerned considers that the possibility of reaching agreement by negotiation has been exhausted. Under section 1 of Part XV the referral of a dispute to settlement by such means, i.e. mediation, conciliation or enquiry, has to be with the agreement of both the States concerned. By contrast, one party may refer a delimitation dispute unilaterally for settlement by judicial means (the ICJ, the International Tribunal for the Law of the Sea (ITLOS) or arbitration) unless the other party has made a declaration under Article 298 of the Losc excluding the delimitation of maritime boundaries from the compulsory judicial settlement procedures of Part XV. At the present time only around one-quarter of States parties to the LOSC have made such a declaration. ${ }^{22}$ Where one party has made such a declaration, the other party may, provided certain conditions are fulfilled, unilaterally initiate conciliation proceedings. ${ }^{23} \mathrm{~A}$ further exception to the use of judicial means under Part XV of the LOSC is if there is an agreement between the States concerned to refer disputes relating to the LOSC to some other judicial means, for example if both States have made declarations under Article $36(2)$ of the ICJ's Statute (the optional clause). ${ }^{24}$

\subsection{The Obligation to Make Every Effort to Enter into Provisional Arrangements of a Practical Nature Pending an Agreement ${ }^{25}$}

According to the arbitral tribunal in the Guyana/Suriname case, the obligation to make every effort to enter into provisional arrangements of a practical nature

22 For a list of States that have made declarations, see http://www.un.org/depts/los/settlement_of_disputes/choice_procedure.htm; accessed 26 June 2019.

23 LOsc, above (n 6), Art 298(1)(a). The first, and so far only, instance of such conciliation was when Timor-Leste initiated conciliation proceedings against Australia in 2016. See Conciliation Proceedings between the Government of the Democratic Republic of Timor-Leste and the Government of the Commonwealth of Australia, Report and Recommendations, 9 May 2018, PCA Case No 2016-10.

24 LOSC, above (n 6), Art 282. On the relationship between such other agreements and Part XV of the LosC, see Somalia $v$ Kenya case, above (n 12), paras 107-133.

25 For more detailed treatment of this issue, see BIICL Report, above (n 3), 13-18 and literature cited there. 
is designed to promote interim regimes and practical measures that could pave the way for provisional utilization of disputed areas pending delimitation. In the view of the Tribunal, this obligation constitutes an implicit acknowledgment of the importance of avoiding the suspension of economic development in a disputed maritime area, as long as such activities do not affect the reaching of a final agreement. ${ }^{26}$

The obligation in Articles 74(3) and 83(3) is 'to make every effort' to enter into provisional arrangements. According to the Special Chamber of the ITLOS in the Ghana/Côte d'Ivoire case, this is an obligation of conduct, not of result. Thus, it does not amount to an obligation to reach an agreement on a provisional arrangement, although there is a duty to act in good faith. ${ }^{27}$ The tribunal in the Guyana/Suriname case amplified this latter point by observing that ' $[t]$ he language in which the obligation is framed imposes on the Parties a duty to negotiate [a provisional arrangement] in good faith' and requires them to take 'a conciliatory approach to negotiations, pursuant to which they would be prepared to make concessions in the pursuit of a provisional arrangement'. ${ }^{28}$ The Special Chamber in the Ghana/Côte d'Ivoire case held that a party to an undelimited maritime boundary dispute does not breach the obligation to make every effort to enter into a provisional arrangement unless it has been asked by the other party to negotiate such an arrangement and it has declined to do so. ${ }^{29}$ It would thus appear to follow that in practice the obligation does not arise for either party until such a request has been made.

The LOsC does not prescribe or indicate what form a provisional arrangement should take or what its content should be. The term 'arrangement' would suggest that a provisional arrangement may take various forms, ranging from a treaty to more informal and even non-legally binding agreed measures. ${ }^{30}$ The requirement in Article 74(3) and 83(3) that a provisional arrangement be of a 'practical nature' indicates that the arrangement should address the practical issues to which overlapping claims give rise, in particular the exploitation of resources (as suggested by the Guyana/Suriname case ${ }^{31}$ ) and the exercise

26 Arbitration between Guyana and Suriname, Award, (2007) XXX RIAA 1, para 46o (footnotes omitted).

27 Ghana/Côte d'Ivoire case, above (n 12), para 627.

28 Guyana/Suriname case, above (n 26), para 461.

29 Ghana/Côte d'Ivoire case, above (n 12), para 628.

30 On the question of when less formal instruments may be legally binding, see the South China Sea Arbitration (The Republic of Philippines $v$ The People's Republic of China), Award on Jurisdiction and Admissibility, 29 October 2015, PCA Case No 2013-19, paras 213-218. See Guyana/Suriname case, above (n 26), paras 46o-464. 
of jurisdiction. Anderson and van Logchem suggest that the content of an arrangement can range widely, including a co-operative arrangement or joint regime that permits the exploration and exploitation in an undelimited area to proceed, a partial or total moratorium on certain types of activity such as drilling, or simply an arrangement of prior notification of a proposed activity in the undelimited area followed by consultations. ${ }^{32}$ According to the Timor-Leste/ Australia Conciliation Commission, a conciliation commission acting under Article 298(1)(a) of the LOSC is competent to propose provisional arrangements as part of its functions. ${ }^{33}$

In practice provisional arrangements, at least those that are publicized, ${ }^{34}$ usually take one of two main forms - a provisional boundary line or an area of joint management. A good example of a provisional boundary is an agreement between Algeria and Tunisia concluded in 2002 that established a provisional single maritime boundary between the two States..$^{35}$ The preamble to the agreement refers to Articles 74(3) and 83(3) of the LOSC, while Article 4 states that the agreement is without prejudice to the final delimitation of the maritime boundary. ${ }^{36}$

Provisional arrangements in the form of a joint management or exploitation zone take various forms and may relate to a particular activity or a number of activities. Some arrangements are concerned only with the exploitation of seabed resources. A good example is an agreement between Nigeria and São Tomé e Príncipe of 2001 which establishes a joint development zone, in an area where their EEZs overlap, for the orderly exploration and exploitation of petroleum and other resources. ${ }^{37}$ The agreement deals, inter alia, with the

32 D Anderson and Yvan Logchem, 'Rights and Obligations in Areas of Overlapping Maritime Claims' in S Jayakumar, T Koh and R Beckman (eds), The South China Sea Disputes and the Law of the Sea (Edward Elgar, 2014) 192-228, 206.

33 Timor-Lest/Australia Conciliation Commission, Decision on Competence, above (n 21), para 97.

34 It is possible that there are informal arrangements whose existence is not generally publicized outside of the States concerned.

35 Agreement on Provisional Arrangements for the Delimitation of the Maritime Boundaries between the Republic of Tunisia and the People's Democratic Republic of Algeria, adopted 11 February 2002, in force 23 November 2003, 2238 UNTS 197. For further examples of provisional boundary agreements, see BIICL Report, above (n 3), 40-116 passim.

36 It has been reported that a definitive boundary agreement was signed in 2011: see WikiLeaks, 'The Global Intelligence Files: Algeria/Tunisia' (released 15 November 2013), https://wikileaks.org/gifiles/docs/20/205385o_-os-algeria-tunisia-algeria-tunisia-inkagreement-on.html; accessed 26 June 2019.

37 Treaty between the Federal Republic of Nigeria and the Democratic Republic of São Tomé e Príncipe on the Joint Development of Petroleum and Other Resources, in respect of Areas of the Exclusive Economic Zone of the Two States, adopted 21 February 2001, 
establishment of joint bodies to manage the development of the zone, the sharing of revenue between the parties, the laws and regulations to be applied in the zone, and environmental protection. The preamble to the agreement refers to Article 74(3) of LOSC and states that the agreement is 'without prejudice to the eventual delimitation of their respective maritime zones by agreement in accordance with international law'. The agreement is to remain in force for 45 years, with a review after 30 years. ${ }^{38}$ That might be thought to be a very long time for a 'provisional' arrangement, but a lengthy period is necessary if oil companies are to have the desired security for their investments.

An example of a provisional arrangement establishing a joint management or exploitation zone for fisheries, albeit concluded before the adoption of the LOSC, is an agreement between Norway and the then USSR, concluded in $1978 .^{39}$ The agreement applied to an area in the southern part of the Barents Sea where the EEZs of Norway and the USSR overlapped. Within that area total allowable catches, quotas and other regulatory measures were adopted by a bilateral Norwegian/Soviet (later Russian) Fishery Commission. Each party had jurisdiction in the area only in respect of its own fishing vessels and such third State vessels as it had licensed to fish against its quota. The agreement was originally concluded for one year only, but contained an option for annual renewals thereafter. That option was exercised continuously until the entry into force in 2011 of a 2010 treaty establishing a definitive maritime boundary between Norway and Russia, when the agreement lapsed. ${ }^{40}$

In some cases joint management or exploitation zones as a form of provisional arrangement have been established to deal with a number of different matters. A good example is an agreement between Barbados and Guyana, concluded in 2003, that establishes a 'co-operation zone for the exercise of joint jurisdiction, control, management, development, and exploration and exploitation of living and non-living natural resources, as well as all other rights and duties established in' the LOSC, in a small area where their EEZs

in force 16 January 2003, http://www.un.org/Depts/los/LEGISLATIONANDTREATIES/ PDFFILES/TREATIES/STP-NGA2001.PDF; accessed 26 June 2019.

$38 \quad$ Ibid Art 51.

39 Agreement between Norway and the Soviet Union on a Temporary Practical Arrangement for Fishing in an Adjacent Area in the Barents Sea, 11 January 1978, in force 27 April 1978, [1978] Overenskomster med fremmede Stater [Norwegian Treaty Series] 436. English translation in Case concerning Maritime Delimitation in the Area between Greenland and Jan Mayen (Denmark v Norway), Counter-Memorial of Norway, Vol II, p 23 .

40 Treaty between the Russian Federation and the Kingdom of Norway concerning Maritime Delimitation and Cooperation in the Barents Sea and the Arctic Ocean, adopted 15 September 2010, in force 7 July 2011, 2791 UNTS 1. 
overlap and which is beyond the EEZ of any third State. ${ }^{41}$ The preamble to the agreement recognizes 'the relevance and applicability' of Article 74(3) of LosC. Article 2(1) of the agreement states that 'the parties contemplate that they may, by agreement at a later date, delimit an international maritime boundary between them', and Article 1(2) provides that the agreement is without prejudice 'to the eventual delimitation of the Parties' respective maritime zones.' ${ }^{42}$

As noted above, in the Ghana/Côte d'Ivoire case the Special Chamber held that one party cannot claim that the other party is in breach of the obligation to 'make every effort to enter into provisional arrangements of a practical nature' unless it has requested the other party to enter into negotiations. That raises the question of at what point in time it may make such a request. In theory, it would seem to be possible to do so as soon as it becomes evident that the States concerned have maritime zones that overlap and therefore require delimitation. In practice, a State might not want to make a request unless and until it had become evident that it and the other State were unlikely to reach agreement on a maritime boundary easily and quickly. If they were likely to reach agreement easily, it would be pointless to hold up negotiations by discussing possible provisional arrangements. Furthermore, if in practice no maritime activities were taking place in the undelimited area, there would be no purpose in seeking an agreement on provisional arrangements.

It would seem from the opening words of Articles 74(3) and 83(3) ('pending agreement') that a provisional arrangement will continue until a definitive maritime boundary is established, either by agreement between the parties or by a court, unless a contrary intention is expressed in the arrangement. Examples of the latter are the Algeria/Tunisia arrangement, discussed above, which provided that it was to remain in force for six years, after which the parties undertook to agree on a definitive maritime boundary or to extend or revise the agreement: ${ }^{43}$ and the Nigeria/São Tomé e Príncipe arrangement, which is to remain in force for 45 years, with a review after 30 years. ${ }^{44}$

41 Treaty between the Republic of Guyana and the State of Barbados concerning the Exercise of Jurisdiction in their Exclusive Economic Zones in the Area of Bilateral Overlap within each of their Outer Limits and beyond the Outer Limits of the Exclusive Economic Zones of Other States, adopted 2 December 2003, in force 5 May 2004, 2277 UNTS 201. It should be noted that the co-operation zone is not necessarily beyond the continental shelf of any third State.

42 For further examples of provisional arrangements in the form of a joint management or exploitation zone, see BIICL Report, above (n 3), pp 40-116 passim.

43 Agreement, above (n 35), Arts 9, 10.

44 Agreement, above (n 37), Art 51. 
Because a provisional arrangement is, according to Articles 74(3) and 83(3), 'without prejudice to the final delimitation', the arrangement, and activities undertaken thereunder, cannot, unless the States concerned expressly agree otherwise, create acquired rights to the undelimited area or its resources, require the States concerned to take the arrangement into account in their negotiations on a maritime boundary, or prevent them from taking a position in those negotiations that is inconsistent with the provisional arrangement. ${ }^{45}$

\subsection{The Obligation Not to Jeopardize or Hamper the Reaching of a Boundary Agreement ${ }^{46}$}

In the Guyana/Suriname case the tribunal observed that the obligation, set out in Articles 74(3) and 83(3) of the LOSC, 'not to jeopardize or hamper the reaching of the final [maritime boundary] agreement' is 'an important aspect of the [Law of the Sea] Convention's objective of strengthening peace and friendly relations between nations and of settling disputes peacefully. However, it is important to note that this obligation was not intended to preclude all activities in a disputed maritime area, ${ }^{47}$ The obligation raises three main questions: (1) what is its substantive scope? (2) what is its geographic scope? and (3) what is its temporal scope?

2.4.1

The Substantive Scope of the Obligation Not to Jeopardize or Hamper

As regards the substantive scope of the obligation, the LOSC does not define the terms 'jeopardize' and 'hamper', nor does it suggest what types of conduct are covered by those terms. The matter has to date been considered by two judicial bodies, the arbitral tribunal in the Guyana/Suriname case and the Special Chamber of the IT Los in the Ghana/Côte d'Ivoire case. Both cases were concerned with hydrocarbon activity in an undelimited area pending its delimitation. However, the two bodies took markedly different approaches to the substantive scope of the obligation not to jeopardize or hamper.

In the Guyana/Suriname case, the tribunal held that drilling for hydrocarbons in an area claimed by both parties was a breach of the obligation. However, the language in which it explained why that was so is not consistent.

45 See R Lagoni, 'Interim Measures Pending Maritime Delimitation Agreements' (1984) 78 American Journal of International Law 345-368, 359.

46 For more detailed treatment of this issue, see BIICL Report, above (n 3), 21-35 and literature cited there. However, that part of the Report now needs to be read in the light of the Ghana/Côte d'Ivoire case, discussed below.

Guyana/Suriname case, above (n 26), para 465. 
The tribunal began by stating that 'unilateral acts which do not cause a physical change to the marine environment' would 'generally' not breach the obligation, whereas 'acts that do cause physical change ... may hamper or prejudice the reaching of a final agreement on delimitation' ${ }^{48}$ However, the tribunal gives four further definitions of actions that (are likely to) breach the obligation not to jeopardize or hamper. They are: 'activities of the kind that lead to a permanent physical change'; 49 'unilateral activity that might affect the other party's rights in a permanent manner'; 50 'activities having a permanent physical impact on the marine environment'; 51 and activities that 'cause permanent damage to the marine environment'.52 This list of activities falls into two broad categories: activities that cause (permanent) physical change or damage to, or have a (permanent) physical impact on, the marine environment; and activities that might affect the other party's rights in a permanent manner. While the activities in the first category are broadly similar, although they differ as to the permanency or otherwise of their adverse effects, the latter category is conceptually quite different and alludes to one of the requirements for the prescription of provisional measures. ${ }^{53}$ It is debatable whether such a test is appropriate to the obligation not to jeopardize or hamper in Articles 74(3) and 83(3), ${ }^{54}$ and in any case the test is probably too strict, as it is possible to envisage conduct that does not affect the other party's rights in a permanent way, yet that would clearly seem to be jeopardizing or hampering. The tribunal suggested that seismic exploration in an undelimited area would not fall into either of its two broad categories and therefore 'should be permissible.' ${ }^{55}$ However, as van Logchem points out, there could be situations where even seismic testing by one party could affect the other party's rights or would be regarded by it as jeopardizing the prospects of a maritime boundary agreement because the information gained by the State carrying out the testing would give it an

48 Ibid para 467. The Tribunal found support for its view in Aegean Sea Continental Shelf (Greece v Turkey), Interim Measures of Protection, Order, ICJ Reports 1976, p 3, para 30. Van Logchem criticizes the tribunal for its reliance on this case: see Y van Logchem, 'The Scope for Unilateralism in Disputed Maritime Areas' in C Schofield, S Lee and M-S Kwon (eds), The Limits of Maritime Jurisdiction (Martinus Nijhoff, 2014) 175-197, 186-191. Guyana/Suriname case, above (n 26), para 467.

50 Ibid para 470.

51 Ibid.

$52 \quad$ Ibid para 481 .

53 See further van Logchem, above (n 48), 184-185.

54 Ibid 191.

55 Guyana/Suriname case, above (n 26), para 481. Cf. also para 467 , where there is a less qualified statement as to the permissibility of seismic testing. 
advantage over the State with whom the boundary was disputed. ${ }^{56}$ In a similar vein, Ioannides argues that recent scientific research suggests that seismic testing may have a serious impact on the marine environment that is irreversible and could be further jeopardizing because data obtained from the testing might be made available to a third State. ${ }^{57}$

In the Ghana/Côte d'Ivoire case, Côte d'Ivoire argued that Ghana breached the obligation not to jeopardize or hamper by engaging in the exploration and exploitation of hydrocarbons in the disputed area before the Special Chamber delimited the boundary. In response, the Special Chamber began by noting that the phrase 'shall make every effort' in Article 83(3) applied to both provisional arrangements and the obligation not to jeopardize or hamper, thereby qualifying the latter as an obligation of conduct. The Special Chamber disagreed with Côte d'Ivoire that Ghana's activities in the disputed area during the period after it realized that that area was also claimed by Côte d'Ivoire, which appears to have been in 2009, had jeopardized or hampered the reaching of a final agreement. That was so for two reasons. First, Ghana had suspended drilling operations in the disputed area following an order of provisional measures made by the Special Chamber in 2015. However, the Chamber added that it would 'have been preferable if Ghana had adhered to the request of Côte d'Ivoire earlier to suspend its hydrocarbon activities in [the undelimited] area.'58 This reasoning is unconvincing. The period to which the obligation applies (discussed in section 2.4.3 below) clearly began well before the order of provisional measures. To say that it 'would have been preferable' if Ghana had ceased its activities before the provisional measures order is to confuse a legal obligation with an apparently moral one. It is also difficult to reconcile the Special Chamber's decision with the tribunal's findings in the Guyana/Suriname case. The second reason given by the Special Chamber as to why Ghana had not breached the obligation not to jeopardize or hamper was because Ghana had only undertaken activities in the area attributed to it by the Special Chamber's line of delimitation, whereas Côte d'Ivoire had claimed a breach of Article 83(3) by Ghana in respect of its activities in the 'Ivoirian maritime area'. ${ }^{9}$ Again, this is not convincing as it gives Ghana the benefit of what is arguably simply a drafting technicality.

\footnotetext{
$5^{6}$ Van Logchem, above (n 48), 184-185.

57 Ioannides, above (n 5), 363, 368 .

58 Ghana/Côte d'Ivoire case, above (n 12), para 632. The discussion of the case in this section draws heavily on R Churchill, 'Dispute Settlement in the Law of the Sea: Survey for 2017' (2018) 33(4) International Journal of Marine and Coastal Law 653-682, 656-667. 
Had Côte d'Ivoire been claiming compensation in respect of Ghana's alleged breach of Article 83(3), the Special Chamber's approach might perhaps have been perhaps more understandable, but in fact Côte d'Ivoire was seeking no more than a declaration of Ghana's breach. Unfortunately, the Special Chamber's approach to the obligation in this case may send the wrong signal to other States with unresolved maritime boundaries. ${ }^{60}$

In a separate opinion, Judge Paik expressed considerable disagreement with this approach. Although he voted for the operative part of the judgment, that was only because Côte d'Ivoire had limited its claim to the 'Ivorian maritime area.' 'Leaving that formalistic reason aside', he had 'serious reservations about the correctness of Ghana's activities in the disputed area in terms' of Article $83(3) \cdot{ }^{61}$ The reasons set out in the judgment in support of its conclusion were 'insufficient and unconvincing. ${ }^{62}$ As to what actions would jeopardize or hamper the reaching of a final boundary agreement, Judge Paik considered that there was no purpose in attempting to identify in general and in the abstract what actions were permissible and what were not. However, 'a key criterion is whether the actions in question would have the effect of endangering the process of reaching a final agreement or impeding the progress of negotiations to that end', ${ }^{63}$ For Judge Paik, the answer to that question would very much depend on the individual circumstances in each case, such as the type, nature, location and time of the actions in question, as well as the manner in which they were carried out. ${ }^{64}$ In the present case Ghana had carried out extensive drilling activities in the disputed area in spite of Côte d'Ivoire's repeated requests that it should abstain from unilateral action. That was clearly a breach of Article 83(3) and it was irrelevant that the disputed area was eventually allocated to Ghana by the Special Chamber's delimitation. Judge Paik's approach

6o For similar criticisms of the Special Chamber's approach, see N Bankes, 'ITLOs Judgment in the Maritime Boundary Dispute between Ghana and Côte d'Ivoire', Jebsen Centre for the Law of the Sea, Tromsø (JCLOS) Blog, posted 27 October 2017, http://site.uit.no/nclos/ 2017/10/27/itlos-judgment-in-the-maritime-boundary-dispute-between-ghana-andcote-divoire/; accessed 26 June 2019; N Ermolina and C Yiallorides, 'State Responsibility for Unilateral Hydrocarbon Activities in Disputed Maritime Areas: The Case of Ghana and Côte d'Ivoire and its Implications', JCLOS Blog, posted 23 November 2017, http:// site.uit.no/nclos/2017/11/23/state-responsibility-for-unilateral-hydrocarbon-activitiesin-disputed-maritime-areas-the-case-of-ghana-and-cote-divoire-and-its-implications/; accessed 26 June 2019; Ioannides, above (n 5), 364-365.

61 Ghana/Côte d'Ivoire case, above (n 12), Separate Opinion of Judge Paik, para 1.

62 Ibid.

63 Ibid para 6. Anderson and van Logchem had earlier expressed similar views: see Anderson and van Logchem, above (n 32), 206; Van Logchem, above (n 48), 186.

64 Separate Opinion of Judge Paik, above (n 61), paras 6, 10. 
to Article 83(3) is far more convincing and satisfactory that than of the judgment, and it is to be regretted that the other judges did not apparently share his views.

Both the Guyana/Suriname and Ghana/Côte d'voire cases were concerned with the meaning and scope of the obligation not to jeopardize or hamper in relation to hydrocarbon resources of the seabed. The position in relation to the living resources of the superjacent water column may well be rather different. ${ }^{65}$ In seeking to establish what the position is, one should take into account the tribunal's dictum in the Guyana/Suriname case (quoted earlier ${ }^{66}$ ) that the obligation not to jeopardize or hamper is not intended to preclude all activities in a disputed maritime area; the provisions of Articles 61-63 of the LOSC (which require coastal States both to promote the optimum utilization of the living resources of their EEzs and to ensure that they are not endangered by over-exploitation, as well as to co-operate over the management of shared stocks); and the renewable nature of fish stocks. The mutual 'due regard' obligation of the coastal and other States found in Article $56(2)$ and $58(3)$, respectively, might also be relevant. Those considerations would suggest that in general the States concerned could permit their vessels to fish in an undelimited area, without the likelihood of jeopardizing or hampering negotiations on a boundary, provided that they did so at a level that their combined activities did not lead to the over-exploitation of resources. That would require those States to exchange information about the level of their fishing activities and to terminate fishing once a sustainable level of fishing was about to be exceeded. ${ }^{67}$ However, any attempt by one State to arrest vessels of the other State that were fishing, whether before or after the fishery had been closed, would be likely to be regarded as provocative and as jeopardizing the prospects of reaching agreement on a boundary, and therefore should be regarded as conduct that would breach the obligation not to jeopardize or hamper. ${ }^{68}$

65 Reasons of space preclude discussion of the position concerning a coastal State's other rights in the water column of the EEz. For such a discussion, see BIICL Report, above (n 3), 28-29; Ioannides, above ( $\mathrm{n} 5$ ), 367 .

66 See the text above at n 47; see also Guyana/Suriname case, above (n 26) para 470.

67 A similar approach was taken by the ILA's Committee on the Exclusive Economic Zone in its 1992 report: see ILA, Report of the Seventy-Sixth Conference (1992) 254, 275-276.

68 So, too, Anderson and van Logchem, above (n 32), 219; van Logchem, above (n 48), 193. In the Guyana/Suriname case, above (n 26), the tribunal regarded the threat of force by Suriname against a drilling rig licensed by Guyana as a breach of the obligation not to jeopardize or hamper (see para 484). The arrest of fishing vessels will often involve some threat of force to vessels that resist arrest. 
Fishing by vessels from third States in an undelimited area raises particular difficulties. Any attempt by one of the States concerned unilaterally to license third State vessels to fish in the area or to arrest third State vessels that were either unlicensed or breaching the conditions of their licence might well be regarded by the other State concerned as breaching the obligation not to jeopardize or hamper. On the other hand, if no action is taken against third State vessels, it is likely that such vessels will fish in the undelimited area and that they will do so at a level that leads to the over-exploitation of stocks, as has happened in some parts of the world. If the two coastal States wish to prevent that happening, they may have little option but to enter into some form of provisional arrangement to address the issue of third State fishing in the undelimited area, as Norway and the then Soviet Union did in the agreement referred to above. ${ }^{69}$

The BIICL report, while not comprehensive in its geographical coverage, records a considerable amount of State practice relating to the obligation not to jeopardize or hamper, both as regards seabed and water column rights. ${ }^{70}$ The question arises as to whether that practice is such that it may be used to provide further interpretation of the LOSC's obligation not to jeopardize or hamper, beyond the interpretation offered by the two judicial decisions discussed above, in accordance with Articles 31(3)(b) and 32 of the Vienna Convention on the Law of Treaties. Article 31(3)(b) provides that in interpreting a treaty, account shall be taken of 'any subsequent practice in the application of the treaty which establishes the agreement of the parties regarding its interpretation'. Article $3^{2}$ is concerned with supplementary means of interpretation. According to the International Law Commission (ILC), those means include subsequent practice other than that referred to in Article 31(3)(b). ${ }^{71}$ The ILC defines such other practice as 'conduct by one or more parties in the application of the treaty, after its conclusion: ${ }^{\prime 2}$

As far as Article 31(3)(b) of the Vienna Convention is concerned, practice that predates the 'conclusion' of the LOsC is clearly not relevant. Postconclusion practice is between pairs of States. It is doubtful whether practice of this nature, even if considerable in extent, can be said to 'establish the agreement of the parties regarding the interpretation of' the LOsc. According

\footnotetext{
$69 \quad$ See (n 39).

70 See BIICL Report, above (n 3), 40-116 passim.

71 International Law Commission, Draft Conclusions on subsequent agreements and subsequent practice in relation to the interpretation of treaties, adopted by the Commission at its 7oth Session, 2018, UN Doc A/CN.4/L.907 (2018) 120, Draft Conclusion 2(4). Ibid Draft Conclusion 4(3). Cf. also Draft Conclusion 6(3).
} 
to the ILC, the identification of subsequent practice requires 'a determination whether the parties, by ... a practice, have taken a position regarding the interpretation of the treaty'. ${ }^{73}$ However, practice evidencing recognition of an obligation of restraint hardly ever makes explicit reference to the obligation in Articles 74(3) and 83(3). It seems unlikely, therefore, that such practice can be taken as showing that the parties concerned 'have taken a position regarding the interpretation' of Articles 74(3) and 83(3). Furthermore, Article 31(3) (b) and the ILC draft conclusions also appear to suggest that practice must evidence a collective view of the parties as to the meaning of a provision. ${ }^{74}$ That is also the view of Aust, who argues that for practice to fall within Article 31(3) (b) it must be 'consistent and ... common to, or accepted, expressly or tacitly, by both or all parties' to a treaty. ${ }^{75}$ It must be doubted whether existing State practice meets that test.

As regards subsequent practice under Article 32 of the Vienna Convention, the ILC states that " $\mathrm{t}]$ he identification of subsequent practice under Article 32 requires, in particular, a determination of whether conduct by one or more parties is in application of the treaty. ${ }^{76}$ As already mentioned, such examples of State practice as do indicate an acknowledgment of an obligation of restraint rarely refer to Articles 74(3) and 83(3) of the LOSC. It is unlikely, therefore, that there is sufficient practice 'in application' of those Articles to constitute an accepted interpretation of them.

\subsubsection{The Geographic Scope of the Obligation Not to Jeopardize or Hamper}

Having examined the substantive scope of the obligation not to jeopardize or hamper, the next question is its geographic scope. ${ }^{77}$ In an undelimited area where the maritime zones of two States overlap, there are likely to be areas that each State accepts belong incontestably to only one or other of them and therefore are not in dispute. Often a State will make it clear at an early stage where it considers that the boundary should lie and will stick to that position until a compromise emerges in the negotiations or a court or tribunal determines the boundary. For example, Norway consistently took the view, prior to

73 Ibid Draft Conclusion 6(1).

74 Cf. ibid Draft Conclusion 10(2).

75 A Aust, Modern Treaty Law and Practice (3rd ed, Cambridge University Press, 2013) 215.

76 International Law Commission, above (n 71), Draft Conclusion 6(3).

77 The discussion of this question that follows does not include, for reasons of space, the question of geographic scope in areas where title to territory generating overlapping claims is disputed. For such discussion, see the BIICL Report, above (n 3), 33-35. 
the conclusion of a maritime boundary agreement with Russia in 2010, that its continental shelf and EEz boundary with Russia in the Barents Sea should be an equidistance line, whereas Russia took the view that the boundary should be a sector line, that is, the line of longitude running northwards from the terminus of the land border. Where two States have advocated different boundary lines in this way, the area between those lines may be referred to as the 'disputed area'. It may be argued that in that situation the obligation not to jeopardize or hamper applies only in the disputed area. ${ }^{78}$

That raises the question of what happens where only one or neither party has advocated a boundary line, or the line advocated by one of the parties is plainly unreasonable in the light of international jurisprudence on maritime boundary delimitation. In its order of provisional measures in the Ghana/Côte d'Ivoire case, the Special Chamber of the ITLOs applied a test of plausibility to determine whether Côte d'Ivoire had continental shelf rights that could be the object of protection by provisional measures. ${ }^{79}$ Applying that reasoning by analogy, one could argue that the obligation not to jeopardize or hamper would not apply to those parts of the area where the maritime zones of the States concerned overlapped that could not plausibly be claimed by more than one of them as its maritime zone. Admittedly, that is a rather imprecise test. If there is doubt about a particular area, the States concerned would be advised to exercise restraint.

A more nuanced approach to the geographic scope of the obligation not to jeopardize or hamper is to argue that the obligation is not binary, i.e. it applies in certain areas but not in others, but rather that it varies qualitatively depending on the area and activity concerned. Certain types of activity may be prohibited completely within those parts of the undelimited area where a neighbouring State's claims are strongest, but may be permitted to some degree where the neighbouring State's claim is weaker, and dependent, for example, on an evaluation of applicable relevant circumstances. Again that is a rather imprecise test, and so States would be well advised to err on the side of caution if they seek to apply it.

A further approach is to reject the notion of geographic limits to the obligation altogether, and instead evaluate conduct, wherever carried out, on its propensity to jeopardize or hamper the reaching of a maritime boundary

78 Ioannides and Lagoni take the same position: see Ioannides, above ( $\mathrm{n}$ 5), 364; Lagoni, above (n 45), 356-357.

79 Dispute concerning Delimitation of the Maritime Boundary between Ghana and Côte d'Ivoire in the Atlantic Ocean (Ghana/Côte d'Ivoire), Provisional Measures, Order of 25 April 2015, ITLOS Reports 2015, p 146, paras 58,62. 
agreement. Such an approach is closer to the text of Article 74(3) and 83(3) and avoids the problems in determining the geographic scope of the obligation outlined above.

\subsubsection{The Temporal Scope of the Obligation Not to Jeopardize or Hamper}

Article 74(3) and 83(3) provide that the obligation not to jeopardize or hamper applies during 'this transitional period'. In the Ghana/Côte d'voire case the Special Chamber held that this phrase refers to 'the period after the maritime delimitation dispute has been established until after a final delimitation by agreement or adjudication has been achieved, 80

\subsubsection{Other Possible Obligations of Restraint in Undelimited Areas of Overlapping EEZs and Continental Shelves}

The Ghana/Côte d'Ivoire case showed that there may be means of restraining the activities of States in undelimited overlapping EEZs and continental shelves other than through the obligation not to jeopardize or hamper. First, Côte d'Ivoire claimed that Ghana had violated its sovereign rights by engaging in exploration and exploitation of hydrocarbons in the disputed area before the boundary had been delimited. It argued that because States' sovereign rights over their continental shelves were inherent and exclusive, international law required a State to refrain from any unilateral economic activity in a disputed area of continental shelf, pending its definitive delimitation, since it might violate the sovereign rights of the other State should the disputed area eventually be attributed to the latter. The Special Chamber rejected that argument, holding that 'maritime activities undertaken by a State in an area of continental shelf which has been attributed to another State by an international judgment cannot be considered to be in violation of the sovereign rights of the latter if those activities were carried out before the judgment was delivered and if the area concerned was the subject of claims made in good faith by both States'.81

That ruling is not very satisfactory. The Special Chamber gave no authority to support its ruling other than a brief quotation from the Nicaragua/Colombia case on a similar, though not identical, point, ${ }^{82}$ which was itself unsupported. It seems difficult to reconcile the Special Chamber's ruling with the obligation not to jeopardize or hamper, at least as interpreted and applied by the tribunal in the Guyana/Suriname case, and the Special Chamber's own order

\footnotetext{
8o Ghana/Côte d'Ivoire case, above (n 12), para 630.

81 Ibid para 592.

82 Nicaragua/Colombia case, above (n 11), para 250.
} 
of provisional measures in the present case (summarized briefly below). The reference to 'claims made in good faith' might suggest that the principle contained in the ruling applied only to those areas of overlap that could plausibly be claimed by both States. However, the Special Chamber's observation that 'in a case of overlap both States concerned have an entitlement to the relevant continental shelf on the basis of their relevant coasts's3 suggests that the principle applies to the whole of the overlapping area. Furthermore, from a policy perspective the principle is undesirable as it may encourage unilateral hydrocarbon activity in disputed areas. The principle as enunciated was probably wider than was necessary to decide the case, since Ghana appears not to have undertaken any activities on what turned out to be Côte d'Ivoire's side of the boundary line (although the Special Chamber did not make any finding on that point). In light of the policy implications referred to, the narrowest possible reading of the Special Chamber's principle should be preferred.

A second possible means of restraint is through the use of provisional measures made by a court in a pending maritime boundary case. ${ }^{84}$ In practice, such measures are rarely requested: in the 25 or so such cases to date, just two requests have been made, and only one of those was successful. That was in the Ghana/ Côte d'Ivoire case, where Côte d'Ivoire had more success than with its other arguments when it persuaded the Special Chamber to make an order of provisional measures in its favour. ${ }^{85}$ That order, inter alia, required Ghana to ensure that no new drilling took place in the disputed area and to prevent information obtained from exploration activities in the disputed area that was not already in the public domain from being used in any way whatsoever to the detriment of Côte d'Ivoire. Provisional measures are, however, of limited utility as a means of restraint, since they can be used only when judicial proceedings for a maritime delimitation have been instituted and they are of relatively short duration.

\section{$3 \quad$ Obligations in Areas of Undelimited Overlapping Continental Shelves beyond $200 \mathrm{M}^{86}$}

There are a considerable number of areas where the continental shelves of opposite or adjacent States beyond 200 M (outer continental shelves)

83 Ghana/Côte d'Ivoire case, above (n 12), para 591.

84 Further on this question, see BIICL Report, above (n 3), 35-39.

85 See (n 73$)$.

86 The BIICL Report, above (n 3), does not deal with this issue, nor the issue of overlapping territorial seas, considered in the following section. 
overlap, or may overlap, depending on what recommendations are made by the Commission on the Limits of the Continental Shelf (CLCS) in respect of outstanding submissions and any further submissions that may be made. ${ }^{87}$ Relatively few overlapping outer continental shelves have so far been delimited, either by agreement ${ }^{88}$ or, except in three cases, by an international court or tribunal. In respect of undelimited overlaps, the obligations of Article 83 , discussed in the previous section, apply. Thus, the States concerned are required to effect a delimitation of their overlapping outer continental shelves by agreement, resort to the dispute settlement procedures of Part XV of the LOSC where no agreement can be reached within a reasonable period of time, make every effort to enter into provisional arrangements of a practical nature pending an agreement, ${ }^{89}$ and not jeopardize or hamper the reaching of a boundary agreement.

While it is clear that Article 83 applies in respect of undelimited outer continental shelves, there is some uncertainty at what point in time its obligations begin to apply, given that, unlike for the inner continental shelf, coastal States do not automatically have a defined outer limit for a continental shelf extending beyond $200 \mathrm{M}$ but must establish its outer limits (if they consider that their continental shelf extends beyond $200 \mathrm{M}$ ), in accordance with the procedure set out in Article 76 and Annex II of the Losc, that is, by making submissions to the CLCS and awaiting the latter's recommendations. One possible answer to the question of when the obligations in Article 83 begin to apply is that it is only when the CLCS has made its recommendations to the States concerned, as it is only at that point that there is an authoritative determination that the continental shelves of those States extend beyond $200 \mathrm{M}$ and that an overlap exists. However, it is arguable that the obligations in Article 83 arise earlier. In the Bangladesh/Myanmar case the ITLOs held that it could delimit the

87 As at 3 September 2020, 5 o of the 85 submissions made up to that date were awaiting recommendations from the CLCS: see http://www.un.org/depts/los/clcs_new/commission submissions.htm; accessed 6 October 2020.

88 For a partial list of such agreements, see вм Magnússon, The Continental Shelf beyond 200 Miles: Delineation, Delimitation and Dispute Settlement (Leiden, Brill, 2015), pp 187-208 who lists 15 agreements as having being concluded by 2015 .

89 There is already at least one example of a provisional arrangement applying to the outer continental shelf: see Mauritius-Seychelles Treaty concerning the Joint Exercise of Sovereign Rights over the Continental Shelf in the Mascarene Plateau Region (adopted 13 March 2012, in force 18 June 2012, 2847 UNTS 277) and Treaty concerning the Joint Management of the Continental Shelf in the Mascarene Plateau Region between the Government of the Republic of Seychelles and the Government of the Republic of Mauritius (adopted 13 March 2012, in force 18 June 2012, 2847 UNTS 307). 
boundary between the continental shelves of Bangladesh and Myanmar, even though neither State had at the time received a recommendation from the CLCS in response to its submission, because there was no 'significant uncertainty' that the two States' continental shelves did indeed extend beyond 200 M.90 Applying that reasoning by analogy, one could argue that the obligations in Article 83 apply once it is clear that there is no 'significant uncertainty' that the outer continental shelves of two or more States overlap.

There is also a strong policy argument that the obligations of Article 83 should become applicable before the CLCS has made a recommendation. Under its Rules of Procedure, the CLCS shall not consider a submission 'where a land or maritime dispute exists' unless all the States that are parties to that dispute have given their prior consent to the CLCs doing so. ${ }^{91} \mathrm{~A}$ considerable number of submissions currently before the CLCS are stalled because of this rule. ${ }^{92}$ In those cases it is desirable that the obligations of Article 83 should apply, not least to avoid exacerbating the dispute and to try to unblock the procedure before the CLCS through the States concerned entering into negotiations on a maritime boundary agreement under Article 83(1), referring it to a third party for resolution in accordance with Article 83(2) or concluding a provisional arrangement.

Article 15 of the LOSC deals with the delimitation of overlapping territorial seas. It reads as follows:

Where the coasts of two States are opposite or adjacent to each other, neither of the two States is entitled, failing agreement between them to the contrary, to extend its territorial sea beyond the median line every point of which is equidistant from the nearest points on the baselines from which the breadth of the territorial seas of each of the two States is measured. The above provision does not apply, however, where it is

$90 \quad$ Bangladesh/Myanmar case (n 11), at paras 444-9.

91 Rules of Procedure of the CLCS, Annex I, para 5(a), available at http://www.un.org/depts/ los/clcs_new/commission_documents.htm\#Rules\%20of\%2oProcedure; accessed 27 June 2019. Note that under Art. 76(10) of the LOsC, delineation of the outer limit of the continental shelf under Art. 76 is 'without prejudice to the question of [its] delimitation'. 
necessary by reason of historic title or other special circumstances to delimit the territorial seas of the two States in a way which is at variance therewith.

This provision is obviously very different from Articles 74 and 83, and on its face lacks a requirement for States with overlapping territorial seas to try to agree a provisional arrangement or exercise restraint pending agreement on a boundary. The difference may be explained by the fact that participants at the Third UN Conference on the Law of the Sea who negotiated the LOSC were happy, when it came to delimitation of territorial sea boundaries, simply to follow the provisions of the 1958 Convention on the Territorial Sea and the Contiguous Zone..$^{93}$ Thus, Article 15 repeats Article 12 of the 1958 Convention almost verbatim. Delimitation of EEZ and continental shelf boundaries was, by contrast, one of the most contentious and intractable issues at the Conference. Eventually a compromise was reached, but the resulting provisions of the LOSC (Articles 74 and 83) are at high level of generality, with the emphasis (as already seen) on procedural matters rather than on the substantive method of delimitation.

Article 15 is commonly considered to be a rule of delimitation, directed at States. In other words, it is regarded as requiring States to delimit the boundary between their overlapping territorial seas as an equidistance line unless historic title or special circumstances indicate a different boundary. However, the ordinary meaning of Article 15 and the drafting history of Article 12 of the 1958 Convention on which Article 15 is based suggest that Article 15 is less a rule of delimitation and more an obligation of restraint. According to its wording, Article 15 deals with the situation where there is no agreement on a territorial sea boundary between States, and requires them to refrain from extending their territorial sea beyond the median line, unless there is a situation of historic title or other special circumstances. That reading is confirmed by the drafting history of Article 15. As mentioned, Article 15 is identical in substance to Article 12 of the $195^{8}$ Convention. The latter, like the rest of the Geneva Conventions, is based on the International Law Commission's Draft Articles on the Law of the Sea. ${ }^{94}$ The ILC had proposed that territorial sea boundaries should be 'fixed by agreement between' the States concerned. 'Failing such agreement and unless another line is justified by special circumstances, the boundary is' the equidistance line. ${ }^{95}$ That is clearly a rule of delimitation: the

\footnotetext{
93 Adopted 29 April 1958, in force 10 September 1964, 516 UNTS 206.

94 (1956) Yearbook of the International Law Commission, Vol II, 254.

95 Ibid Draft Art 12(1) (in relation to opposite States) (emphasis added). Draft Art 14(1) (on adjacent States) is very similar.
} 
boundary is to be agreed; but if there is no agreement, the boundary is the equidistance line, absent special circumstances. At the 1958 UN Conference on the Law of the Sea, the ILC's proposal was rejected and replaced by what is now Article 12 of the 1958 Convention. The main reason for this change appears to have been because the 1958 Conference failed to reach agreement on the breadth of the territorial sea. Without such agreement, as was pointed out by various participants at the Conference, one consequence of the ILC's proposed rule would be that in a situation where two States were opposite one another, and between eight and 12 miles apart, with one State claiming a 12-mile territorial sea and the other a three-mile territorial sea, the latter would end up with a territorial sea of between four and six miles in breadth. ${ }^{96}$

This drafting history therefore supports the view that in the case of undelimited overlapping territorial seas, Article 15 of the LOsC is less a rule of delimitation for States and more an obligation of restraint: the States concerned may not extend their territorial sea beyond the equidistance line unless there are special circumstances or historic title is involved. Article 15 will work quite well as an obligation of restraint provided, first, that neither of the States concerned objects to the baselines used by the other State for constructing an equidistance line; and, second, that there is no dispute over historic title or the existence of special circumstances and their possible effect on modification of the equidistance line. Admittedly, these are rather far-reaching provisos. Unlike the position in relation to the EEZ and continental shelf, there is no obligation on the States concerned to enter into negotiations on a territorial sea boundary or to seek to agree a provisional arrangement. However, it is always possible for one of the States concerned unilaterally to refer delimitation of the territorial sea boundary to a judicial body for settlement under Part XV of the LOSC, ${ }^{97}$ provided that the other State has not made a declaration under Article 298 excluding delimitation disputes from compulsory dispute settlement. If it has done so, compulsory conciliation will be possible if the conditions in Article 298(1) are met.

\section{$5 \quad$ Obligations of States Not Parties to the LOSC}

The overwhelming majority of coastal States are parties to the LOSC. However, as of July 2019 there were 14 coastal States that were not parties and to which

96 United Nations Conference on the Law of the Sea, Official Records, Vol III (1958), 187-193.

97 The 'reasonable time' constraint found in para 2 of Arts 74 and 83 (discussed in section 2.2. above) will not apply to referrals concerning only territorial sea delimitation. 
the obligations of the LOSC therefore do not apply, at least qua treaty provisions. Five of those States (Cambodia, Colombia, Israel, the United States and Venezuela) are parties to the $195^{8}$ Convention on the Continental Shelf.98 Under Article 6 of that Convention there is an obligation on States to determine a maritime boundary by agreement. That would seem to be similar to the obligation on States under Articles 74(1) and 83(1) of the LOSC to seek to agree to a boundary through negotiations. Article 6 also provides that where there is no boundary agreement, the boundary is the equidistance line unless another boundary is justified by special circumstances. Four of the five non-LOsC parties mentioned above (the exception is Colombia) are also parties to the 1958 Convention on the Territorial Sea and the Contiguous Zone. As mentioned earlier, Article 12 of that Convention is identical in substance to Article 15 of the LOSC. Thus, what was said earlier about the obligations in Article 15 will apply equally to Article 12 of the 1958 Convention.

For States that are parties to neither a relevant Geneva Convention nor the LOSC, the only obligations applying in overlapping maritime zones will be those found in customary international law. Those obligations apply not only to States that are not parties to the LOSC but will also govern relations where the maritime zones of such States overlap with a State that is a party. Ascertaining what obligations apply under customary international law in overlapping maritime zones is more straightforward than might be initially supposed. That is because the ICJ has held that Articles 15, 74 and 83 all represent customary international law. ${ }^{99}$ Thus, the obligations that apply in overlapping maritime zones under customary international law are the same as the obligations under the Losc. There is, however, one procedural difference. That concerns the obligation in Articles 74(2) and 83(2) to resort to the dispute settlement procedures of Part XV where no agreement on a maritime boundary can be reached within a reasonable period of time. Clearly the dispute settlement procedures of Part $\mathrm{XV}$ are not available to non-parties to the LOsc. However, it could be argued that the customary law equivalent of Articles 74(2) and 83(2) would be to resort to any third party dispute settlement procedures available to the States concerned: that would include both diplomatic and judicial means, since Part XV is concerned with both.

There are various general obligations of restraint under customary international law that will also be relevant to non-parties to the LOSC, particularly if

98 Adopted 29 April 1958, in force 10 September 1964, 499 UNTS 311.

99 On Art 15, see Maritime Delimitation and Territorial Questions between Qatar and Bahrain (Qatarv Bahrain), Judgment, (2001) ICJ Reports, p 40, para 176. On Arts 74 and 83, see ibid para 167 and the Nicaragua/Colombia case, above (n 11), para 139 . 
there is any doubt that the provisions of the LOSC referred to in the previous paragraph are part of customary international law. ${ }^{100}$ Those general obligations also apply, of course, to parties to the LOSC, although they probably add nothing to its provisions.

In the South China Sea case the arbitral tribunal emphasized that where dispute settlement proceedings were ongoing, there was an obligation on the parties to the dispute not to take any steps that would aggravate or extend the dispute. ${ }^{101}$ One can argue that that principle should extend to the situation where States disagree (i.e., are in dispute) over the course of their maritime boundary.

The 'no harm' principle may also act as an obligation of restraint. The ICJ has held that under customary international law States are obliged to 'ensure that activities within their jurisdiction and control respect the environment of other States'.102 This is a specific application of a more general principle of good neighbourliness in international law, often stated in the Latin maxim 'sic utere tuo, ut alienum non laedas'. ${ }^{103}$ It may thus be argued that States must ensure that activities under their jurisdiction and control respect areas where another State not only undoubtedly has, but also may have, sovereignty or sovereign rights. In other words, a State must refrain from acts that would be a violation of international law if the area where the violation had occurred turned out, following delimitation of the boundary, to be part of the maritime zones of another State. Support for that conclusion is provided by one of the recent Costa Rica/Nicaragua cases, where the ICJ held that dredging and other activities carried out by Nicaragua on territory claimed by both parties violated international law. That was because the Court found that the disputed territory belonged to Costa Rica and Nicaragua had carried out its activities there without Costa Rica's consent. ${ }^{104}$ Admittedly, the position put forward here does not

100 Ioannides argues that the obligations in Arts 74(3) and 83(3) 'have not yet crystallized' into customary international law. However, they reflect general principles of good faith and peaceful resolution of disputes that should be observed by all States. See Ioannides, above (n 5), 368 .

101 South China Sea Arbitration (The Republic of Philippines $v$ The People's Republic of China), Award, 12 July 2016, PCA Case No 2013-19, paras 1167-1173.

102 Advisory Opinion on the Legality of the Use by a State of Nuclear Weapons in Armed Conflict, (1996) ICJ Reports, p 226, para 29; subsequently endorsed in Pulp Mills on the River Uruguay (Argentina v Uruguay), Judgment, (2010) ICJ Reports, p 14, para 101.

103 P Birnie, A Boyle and C Redgwell, International Law and the Environment (3rd ed, Oxford University Press, 2009) 137; see also BD Smith, State Responsibility and the Marine Environment (Clarendon Press, 1988), especially chaps 5 and 6.

104 Certain Activities Carried Out by Nicaragua in the Border Area (Costa Rica v Nicaragua), (2015) ICJ Reports, p 665, especially para 93. 
sit well with the ruling of the Special Chamber in the Ghana/Côte d'voire case rejecting Côte d'Ivoire's argument concerning the alleged violation of its sovereign rights by Ghana, but, as suggested earlier, ${ }^{105}$ that ruling should be treated with caution.

\section{Conclusion}

Worldwide there are some 180 areas where one or more of the maritime zones of two States overlap and have not (yet) been delimited by a boundary. International law lays down a number of obligations relating to such undelimited areas, primarily designed to avoid the lawlessness often associated with undelimited frontier areas and to promote the optimum use of resources. Those obligations vary, depending on the maritime zone at issue. In the case of undelimited overlapping territorial seas, States are required under Article 15 of the LOSC not to extend their territorial sea beyond the equidistance line unless there are special circumstances or issues of historic title.

A rather different set of obligations applies to undelimited overlapping EEZs and continental shelves under Articles 74 and 83 of the LOSC. Here the States concerned must enter into negotiations to try to reach an agreement on the boundary between their overlapping zones. Where they are unable to reach such an agreement within a reasonable period of time, they must resort to the dispute settlement procedures of Part XV of the LOSC. In addition, pending an agreement, they must make every effort to enter into provisional arrangements of a practical nature and refrain from acts that would jeopardize or hamper the reaching of a boundary agreement.

International courts have held that the provisions of Articles 15, 74 and 83 also represent customary international law. Thus, they apply to the 14 coastal States that are not parties to the LOSC as well as to relations between those States and State that are parties, with the proviso that non-parties to the LOSC cannot invoke the latter's dispute settlement procedures. In addition, under customary international law principles, States must refrain from acts that would aggravate their disagreement over the location of their maritime boundary or that would violate the sovereignty or sovereign rights of the other State should the area where those acts take place eventually turn out to be part of that other State's maritime zones.

105 See text following (n 85). 
It is difficult to know how far the obligations of the LOSC surveyed in this chapter have influenced the behaviour of States. Usually one can only guess at the motives for the actions of States since they rarely articulate why they behave in the way that they do. Since the entry into force of the LOSC in 1994, a steady stream of maritime boundary agreements has been concluded. One assumes that the primary motivation is self-interest rather than acting in response to obligations in the LOSC. Where States have been unable to agree, there have so far been relatively few references to dispute settlement under Part XV of the LOSC. There has been one instance of compulsory conciliation and five cases of judicial settlement. ${ }^{106}$ There have also been eleven referrals to judicial settlement where jurisdiction was not based on Part XV, either to the ICJ or an ad hoc arbitral tribunal. ${ }^{107}$ In the majority of those cases one or more of the parties to the case was not a party to the LOSC at the time that the case was referred.

One exception to the failure of States to explain why they act is the provisional arrangements concluded for overlapping Eezs and/or continental shelves, the great majority of which refer explicitly to Articles 74(3) and/or $83(3)$. However, such arrangements have been adopted for only a small number of undelimited areas. There have been relatively few reports of incidents that could be regarded as breaches of the obligations of restraint in undelimited maritime frontier areas, at least in areas where there are not also disputes over title to territory. On this matter States have been particularly reticent about the reasons for their actions (or inactions), so it is impossible to assess the influence (if any) of the relevant law.

106 The Timor-Leste/Australia conciliation, above (n 21); Barbados/Trinidad and Tobago, Guyana/Suriname, Bangladesh/Myanmar, Bangladesh/India and Ghana/Côte d'Ivoire cases (n 11, 12 and 26).

107 In the case of the ICJ, the Qatar/Bahrain case, above (n 99); the Cameroon/Nigeria case, above (n 11); Case concerning Territorial and Maritime Dispute between Nicaragua and Honduras in the Caribbean Sea (Nicaragua v Honduras), Judgment, (2007) ICJ Reports, p 659; the Black Sea case, above (n 11); the Nicaragua/Colombia case, above (n 11); the Peru/ Chile case, above (n 11); Maritime Delimitation in the Caribbean Sea and the Pacific Ocean (Costa Rica v Nicaragua), Judgment, (2018) ICJ Reports, p 100; the Somalia/Kenya case, above (n 12); and Question of the Delimitation of the Continental Shelf between Nicaragua and Colombia beyond 200 nautical miles from the Nicaraguan Coast (Nicaragua v Colombia) (ICJ, pending). The arbitrations have been the Eritrea-Yemen Maritime Delimitation Arbitration (1999), (2006) XXII RIAA 335; and Arbitration between Croatia and Slovenia, Award, 29 June 2017, PCA Case No 2012-04. 